\title{
A novel method to optimise the utility of underused moulted plumulaceous feather samples for genetic analysis in bird conservation
}

\author{
Catherine Peters ${ }^{1}\left[\right.$ [D $\cdot$ Howard Nelson ${ }^{1} \cdot$ Bonnie Rusk $^{2} \cdot$ Anna Muir $^{1}$ \\ Received: 5 April 2019 / Accepted: 17 October 2019 / Published online: 24 October 2019 \\ (C) The Author(s) 2019
}

\begin{abstract}
Non-invasive sampling methods are increasingly being used in conservation research as they reduce or eliminate the stress and disturbance resulting from invasive sampling of blood or tissue. Here we present a protocol optimised for obtaining usable genetic material from moulted plumulaceous feather samples. The combination of simple alterations to a 'user-developed' method, comprised of increased incubation time and modification of temperature and volume of DNA elution buffer, are outlined to increase DNA yield and significantly increase DNA concentration ( $\mathrm{W}=81, \mathrm{p}<0.01$, Cohens's $d=0.89)$. We also demonstrate that the use of a primerless polymerase chain reaction (PCR) technique increases DNA quality and amplification success when used prior to PCR reactions targeting avian mitochondrial DNA (mtDNA). A small amplicon strategy proved effective for mtDNA amplification using PCR, targeting three overlapping 314-359 bp regions of the cytochrome oxidase I barcoding region which, when combined, aligned with target-species reference sequences. We provide evidence that samples collected non-invasively in the field and kept in non-optimal conditions for DNA extraction can be used effectively to sequence a $650 \mathrm{bp}$ region of mtDNA for genetic analysis.
\end{abstract}

Keywords Non-invasive sampling $\cdot$ Feather samples $\cdot$ Polymerase chain reaction (PCR) $\cdot$ Primerless PCR $\cdot$ mtDNA $\cdot$ Small amplicon strategy

\section{Introduction}

Working with cryptic, rare or elusive species can make obtaining invasive samples such as tissue or blood logistically difficult (Mills et al. 2000; Horváth et al. 2005). Moreover, for endangered and sensitive species, it can be difficult to obtain permits for more intrusive sampling methods, which in some cases are considered unethical (Segelbacher 2002). In these cases, biological samples such as feathers,

Electronic supplementary material The online version of this article (https://doi.org/10.1007/s12686-019-01117-8) contains supplementary material, which is available to authorized users.

Catherine Peters

c.peters@chester.ac.uk

1 Biological Sciences Department, University of Chester, Parkgate Road, Chester CH1 4BJ, UK

2 Grenada Dove Conservation Programme, c/o Forestry and National Parks Department, Queen's Park, St. Georges, Grenada hair, buccal cells, faecal matter and shed skin can be collected in the field with minimal disturbance to the study species (Mills et al. 2000; Bohmann et al. 2014). However, some types of non-invasive sample collection such as buccal swabbing and hair plucking still require trapping and handling of the animal (Broquet et al. 2006; Dai et al. 2015), and these methods have the potential to cause stress and affect the behaviour of an individual, even if such effects are short term (Broquet et al. 2006; Rudnick et al. 2009; Dai et al. 2015). Highly non-invasive sample collection of material such as moulted feathers, shed skin, faecal samples or environmental DNA (eDNA), which can be collected opportunistically in the field, can eliminate the need to interact with the study species (Bayard De Volo et al. 2008; Bohmann et al. 2014). This is advantageous, particularly for research on sensitive species and ecosystems, as it minimises the level of disturbance to the wildlife and prioritises the welfare of individuals being investigated (Dai et al. 2015).

Despite the advantages of using highly non-invasive sampling methods, it is often difficult to identify the biological material collected to species-level without genetic analysis 
(Mills et al. 2000; Rudnick et al. 2009). This is a particular problem for samples such as feathers, hair and faecal matter that can often come from a variety of species sharing the same habitat with similar somatic features (Waits and Paetkau 2005; Coghlan et al. 2012; Ahlers et al. 2017). Sample type also has an impact upon the likelihood of successful DNA extraction, for example, large primary, secondary and tail feathers are preferable for obtaining usable genetic material compared to smaller plumulaceous feathers (Dove 2000; Vili et al. 2013). Larger feathers are embedded deeper in the body of the bird and so are more likely to retain DNA containing biological material such as epithelial cells (Seki 2006; Gebhardt and Waits 2008). Primary feathers in particular can contain the umbilicus blood clot in the shaft of the quill which is a by-product of feather development and, if present, provides a plentiful source of DNA (Segelbacher 2002; Vili et al. 2013). However, opportunistic sample collection methods often remove the ability to select for sample type (Broquet et al. 2006). Furthermore, there is often no indication of how long the sample has been in the field and thus exposed to a variety of environmental conditions before collection (Hogan et al. 2008; Vili et al. 2013). Hot and humid environments provide non-optimal conditions for biological samples intended for genetic investigation (McNally et al. 1989; Hanson and Ballantyne 2005) as this can lead to a higher prevalence of decomposing microorganisms such as fungi, mould spores and keratin-degrading microorganisms, which can damage the DNA (Sangali and Brandelli 2000; Vili et al. 2013). The increased likelihood of degraded DNA in such samples reduces and often prevents the selection of non-invasively collected samples for use in genetic analyses (Vili et al. 2013). Therefore, an improved method is needed to increase the biological value of low quality samples which have been kept in non-optimal conditions; particularly for endangered or elusive species for which invasive sampling methods are not possible (Broquet et al. 2006; Hogan et al. 2008; Presti et al. 2013).

In this study we focused on the utility of non-invasively collected feather samples of the critically endangered Grenada dove (Leptotila wellsi). We provide a three-step process to allow successful extraction and amplification of mitochondrial DNA (mtDNA) from plumulaceous feather samples. Firstly, we describe improvements to a user-developed protocol for DNA extraction that increases DNA yield, followed by primerless PCR to improve quality, along with a small amplicon strategy that enabled effective mtDNA amplification using PCR, targeting three overlapping regions of the cytochrome oxidase I (COI) barcoding region.

\section{Methods and results}

\section{Study species and sample collection}

The Grenada dove is a critically endangered columbid, endemic to the island of Grenada (Rosenberg and Korsmo 2001; BirdLife International 2019) with a population size of $160 \pm 30$ individuals (Rivera-Milán et al. 2015). Habitat loss and degradation means that this species exists in small fragmented populations (Rosenberg and Korsmo 2001; Rusk 2008; Rivera-Milán et al. 2015). It is threatened by predation from a number of mammalian species as well as habitat destruction from natural damaging events such as hurricanes (Bolton et al. 2016). Low encounter rates and cryptic behaviour make surveying this species particularly difficult, requiring intensive monitoring that may cause disturbance (Rivera-Milán et al. 2015; Bolton et al. 2016; Rusk 2017). Therefore, non-invasive sampling methods are required to obtain samples for genetic analysis with minimal disruption to this endangered species.

Feather samples used for this study were obtained noninvasively, as moulted feathers, and collected opportunistically from known occupied dove territory: Mount Hartman estate and Perseverance, Grenada (Rusk 2008, 2017). Habitat consists of both dry and mixed broadleaf evergreendeciduous second-growth forests (Rusk 2017). This tropical dry forest habitat has a minimum temperature of $22^{\circ} \mathrm{C}$ and temperatures that can reach up to $32{ }^{\circ} \mathrm{C}$, with a maximum rain fall of $259 \mathrm{~mm}$ in the rainy season and a minimum of $67 \mathrm{~mm}$ in the dry season (Meteostat 2018; Nelson et al. 2018). Due to the opportunistic nature of the sample collection, the feathers used in this study spent an unknown amount of time in the litter bed of this hot and humid environment before collection. Samples were stored in sample bags at $4{ }^{\circ} \mathrm{C}$ until transportation by airmail to the UK in June 2018. On arrival in the UK, the samples were cleaned with $70 \%$ ethanol and stored at $-20^{\circ} \mathrm{C}$. The sample set $(n=160)$ used in this study was comprised of 152 plumulaceous

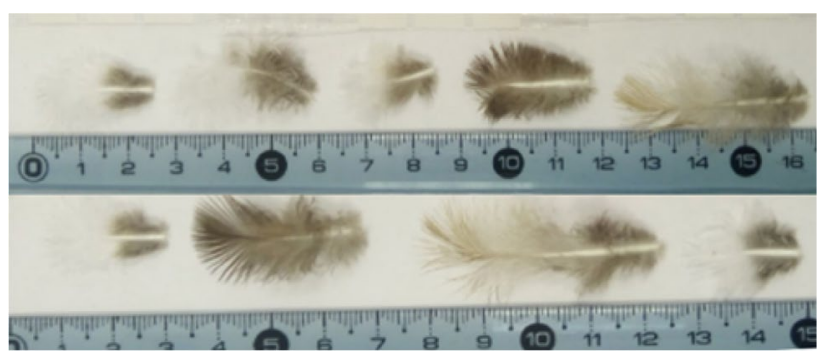

Fig. 1 Examples of the plumulaceous feathers used in this investigation 
(Fig. 1), three secondary and three primary feathers, as well as two egg shells recovered from the forest floor.

\section{DNA extraction}

The commercially available QIAGEN DNeasy® Blood and Tissue kit was used to conduct DNA extraction. Extractions were carried out as per the 'User-Developed Protocol: Purification of total DNA from nails, hair, or feathers using the DNeasy® Blood \& Tissue Kit' (QIAGEN Inc., Crawley) with the following alterations to incubation time, temperature and volume of DNA elution buffer. Feather samples were cut into $1 \mathrm{~cm}$ pieces directly into a sterile $1.5 \mathrm{ml}$ microcentrifuge tube containing the lysis buffers using sterile scissors to increase surface area (Presti et al. 2013). The incubation step was increased to 48 hours in order to achieve complete sample lysis on samples that are particularly difficult to digest (Bush et al. 2005; Bayard De Volo et al. 2008). To increase DNA yield we heated buffer AE (elution buffer) at $70{ }^{\circ} \mathrm{C}$ for $10 \mathrm{~min}$ before use. Buffer $\mathrm{AE}$ contains the organic compound Tris [tris(hydroxymethyl) aminomethane, $\left.\left(\mathrm{HOCH}_{2}\right)_{3} \mathrm{CNH}_{2}\right)$ ] and EDTA [Ethylenediaminetetraacetic acid $\left.\left(\mathrm{C}_{10} \mathrm{H}_{16} \mathrm{~N}_{2} \mathrm{O}_{8}\right)\right]$ which functions to rehydrate the nucleic acids and release DNA from the silica membrane. This process is improved when the DNA and silica are exposed to higher temperatures (Bruns et al. 2007; Zhou and Ling 2011; Haddad et al. 2017). We used an elution volume of $100 \mu \mathrm{l}$ in a two-step process, giving a final volume of $200 \mu \mathrm{l}$ which was subsequently stored at $-20^{\circ} \mathrm{C}$. Although using half the recommended volume of elution buffer decreases the DNA yield, the aim was to increase the final concentration of DNA as it is well documented that a higher concentration of starting DNA in PCR reactions improves the likelihood of successful DNA amplification (Kishore et al. 2006; Rohland and Hofreiter 2007; Graziano et al. 2013).

In order to assess whether the alterations to the protocol had optimised DNA concentration following extraction, we compared the concentration of DNA from samples extracted using the standard manufacturer's protocol and the protocol we have outlined above. DNA concentrations for samples extracted using the standard protocol were obtained from a feather set that arrived in the laboratory in $2016(n=50)$. We used a number generator to randomly select 20 plumulaceous feather samples from the feather set obtained in 2016 and extracted using the standard protocol and from the feather set obtained in 2018 and extracted using the optimised extraction method. The DNA concentration of each sample was quantified using the Invitrogen ${ }^{\mathrm{TM}}$ Qubit $^{\mathrm{TM}}$ 3.0 Fluorometer, which has a DNA detection range of 0.50-600 ng/ml, using dsDNA High Sensitivity settings following the manufacturer's protocol (Table 1). A Shapiro-Wilk test (Shapiro and Francia 1972) indicated that
Table 1 Concentration of DNA (ng/ml) from samples extracted using the standard QIAGEN user developed DNA extraction protocol and samples extracted using the optimised extraction protocol

\begin{tabular}{|c|c|c|c|}
\hline \multicolumn{2}{|c|}{ Standard protocol } & \multicolumn{2}{|c|}{ Optimised protocol } \\
\hline 2016 Samples & $\begin{array}{l}\text { DNA conc. (ng/ } \\
\mathrm{ml})\end{array}$ & 2018 Samples & $\begin{array}{l}\text { DNA conc. (ng/ } \\
\mathrm{ml})\end{array}$ \\
\hline P2 & $<0.50^{\mathrm{a}}$ & M31 & 7.45 \\
\hline P4 & 26.9 & M40 & 10.8 \\
\hline P5 & $<0.50$ & M44 & 1.13 \\
\hline P7 & 13.0 & M46 & 5.18 \\
\hline P8 & $<0.50^{\mathrm{a}}$ & M63 & 3.60 \\
\hline P12 & $<0.50^{\mathrm{a}}$ & M68 & 4.60 \\
\hline M1 & 6.09 & M83 & 1.76 \\
\hline M2 & 1.28 & M95 & 217.67 \\
\hline M5 & 0.56 & M100 & 58.17 \\
\hline M8 & 0.81 & M108 & 1.33 \\
\hline M18 & 0.82 & M114 & 50.7 \\
\hline M19 & 7.92 & M115 & 4.64 \\
\hline M22 & 1.74 & M118 & $<0.50^{\mathrm{a}}$ \\
\hline M23 & 1.35 & P37 & 32.1 \\
\hline M28 & 15.9 & P38 & 307.33 \\
\hline F3 & 1.32 & P39 & 4.50 \\
\hline F4 & 1.23 & $\mathrm{P} 45$ & 45.43 \\
\hline F5 & 0.51 & P49 & 34.13 \\
\hline F6 & $<0.50^{\mathrm{a}}$ & P69 & 2.23 \\
\hline F8 & $<0.50^{\mathrm{a}}$ & F12 & 1.87 \\
\hline Mean & 4.1185 & Mean & 39.7555 \\
\hline Standard error & \pm 1.56 & Standard error & \pm 17.82 \\
\hline Median & 1.03 & Median & 4.91 \\
\hline
\end{tabular}

${ }^{a}$ DNA concentration was too low to read and therefore out of range of the Invitrogen ${ }^{\mathrm{TM}}$ Qubit $^{\mathrm{TM}} 3.0$ Fluorometer (range 0.50-600 ng/ml) using dsDNA High sensitivity settings

the data were not normally distributed $(\mathrm{p}<0.05)$ therefore a Wilcox test (Wilcox 2008) to compare the difference in DNA extracted when using the standard protocol and the optimised protocol outlined in this study. All analyses were performed in $\mathrm{R}$ (R Core Team 2013). The results of the test showed that samples that underwent the optimised protocol had a significantly higher extracted DNA concentration than the standard protocol $(\mathrm{W}=81, p$ value $<0.01$, Cohens's $d=0.89$ ). Samples that were lower than the detection range of the Invitrogen ${ }^{\mathrm{TM}}$ Qubit ${ }^{\mathrm{TM}}$ 3.0 Fluorometer were assigned the value $0.49 \mathrm{ng} / \mathrm{ml}$. Table 1 shows that $30 \%$ of the samples extracted using the standard protocol were of too low concentration to evaluate. In comparison, only $5 \%$ of the samples that were extracted using the optimised protocol had a concentration below the range of the Invitrogen ${ }^{\mathrm{TM}}$ Qubit $^{\mathrm{TM}}$ 3.0 Fluorometer. Therefore, both DNA extraction success rate and DNA concentration were increased by the optimised protocol. 
To test that target DNA, rather than that of subsidiary material, had been extracted and to ascertain the potential presence of PCR inhibitors, which are common when using non-invasively collected samples (Waits and Paetkau 2005; von Thaden et al. 2017), avian cytochrome b (cyt b), was amplified. We designed primers using Primer3 (Koressaar and Remm 2007; Untergasser et al. 2012) based on a cytochrome b sequence from the white-tipped dove (Leptotila verreauxi), whose whole mitochondrial genome is available on GenBank, accession number: NC_015190.1 (Pacheco et al. 2011). The Primer3 output for the designed primers is provided in Online Resource 1. This species was chosen as it has been suggested, based on the ecology of the species, that it is closely related to the Grenada dove (Blockstein and Hardy 1989), although molecular phylogenetic analysis has not yet been carried out for the Grenada dove. The primers were designed to include a 200-250 bp region of the cyt $b$ gene, with a length of around 20 bases long, a GC content of around $50 \%$ and melting temperatures that are no more than $5{ }^{\circ} \mathrm{C}$ apart (Dieffenbach et al. 1993; Naqib et al. 2019). The chosen primers targeted a 203 bp region of cytochrome b gene: CYTB_2 Forward: 5'-CTGCCTACT AACCCAGATCCT-3' and CYTB_2 Reverse: 5'-AGGAGC CGTAGTAGAGTCCT-3'. To prevent contamination of samples, PCR was conducted in a PCR hood where tube racks, pipettes and tubes were exposed to UV light for $20 \mathrm{~min}$ prior to setting up the reaction (Bayard De Volo et al. 2008). PCR was conducted using illustra ${ }^{\mathrm{TM}}$ PuReTaq Ready-To-Go ${ }^{\mathrm{TM}}$ PCR Beads (GE HEALTHCARE; Chicargo) with a final volume of $25 \mu$ containing 2.5 units of recombinant PuReTaq DNA polymerase, $200 \mu \mathrm{M}$ of dNTP's in $10 \mathrm{mM}$ Tris- $\mathrm{HCl}$, $50 \mathrm{mM} \mathrm{KCl}$ and $1.5 \mathrm{mM} \mathrm{MgCl}_{2}$ stabilizers, BSA and reaction buffer, $5 \mu \mathrm{l}$ of DNA template and a negative control using sterile $\mathrm{H}_{2} \mathrm{O}$. PCR was conducted on a TECHNE TC-3000 thermocycler (Bibby Scientific Ltd; Stone) using the following conditions optimised for this primer set: initial denaturation at $95^{\circ} \mathrm{C}$ for $5 \mathrm{~min}, 45$ cycles of $95^{\circ} \mathrm{C}$ for $30 \mathrm{~s}$, $48^{\circ} \mathrm{C}$ for $30 \mathrm{~s}, 72{ }^{\circ} \mathrm{C}$ for $60 \mathrm{~s}$ and a final extension at $72{ }^{\circ} \mathrm{C}$ for $5 \mathrm{~min}$. PCR products were separated by electrophoresis (Westermeier 2005) on a 2\% (Mardis and McCombie 2017) agarose gel (Thermo Fisher Scientific, Waltham) and visualised using a BioRad Gel Doc ${ }^{\mathrm{TM}}$ EZ Imager and Image lab 4.0 software (Bio-Rad Laboratories 2017). DNA extraction using the optimised method resulted in a visible band on the gel at the $203 \mathrm{bp}$ target region of avian cyt b for 154 out of $158(97.5 \%)$ of the feathers being used in this study (Table 2) thus confirming target DNA rather than subsidiary material had been amplified.

\section{Primerless PCR}

Primerless PCR, also known as 'DNA shuffling' or 'sexual PCR', exposes the DNA template to Taq DNA polymerase,
Table 2 Number of successful and failed amplifications of a $203 \mathrm{bp}$ target region of avian cytochrome $b$ gene, recorded by feather type, following DNA extraction using our optimised technique (prior to including the primerless PCR step)

\begin{tabular}{lccl}
\hline Feather type & $\begin{array}{l}\text { Number of } \\
\text { feathers }\end{array}$ & $\begin{array}{l}\text { Number of success- } \\
\text { ful amplifications }\end{array}$ & $\begin{array}{l}\text { Number of failed } \\
\text { amplifications }\end{array}$ \\
\hline Secondary & 3 & $2(66.7 \%)$ & $1(33.3 \%)$ \\
Primary & 3 & $3(100 \%)$ & $0(0 \%)$ \\
Plumulaceous & 152 & $149(98 \%)$ & $3(2 \%)$ \\
Total & 158 & $154(97.5 \%)$ & $4(2.5 \%)$ \\
\hline
\end{tabular}

Amplification was considered successful if a visible band was present on a $2 \%$ agarose gel for the target region

dNTPs and a heating and cooling cycle which serves to denature the sample into smaller fragments which then anneal to each other (Stemmer 1994; Melnikov and Youngman 1999; Brakmann and Schwienhorst 2004; Suenaga et al. 2005; An et al. 2011). This is known as self-priming and functions to repair DNA damage such as nicks, fragmentation, abasic sites and blocked 3 '-ends in degraded DNA samples that may inhibit amplification (Diegoli et al. 2012).

Primerless PCR reactions were conducted using illustra $^{\text {TM }}$ PuReTaq Ready-To-Go ${ }^{\mathrm{TM}}$ PCR Beads with a final volume of $25 \mu \mathrm{l}$ including $5 \mu \mathrm{l}$ of DNA template. Samples were subjected to a PCR cycle with the cycling parameters: initial denaturation at $95{ }^{\circ} \mathrm{C}$ for $5 \mathrm{~min}, 10$ cycles of $95{ }^{\circ} \mathrm{C}$ for $30 \mathrm{~s}, 55^{\circ} \mathrm{C}$ for $30 \mathrm{~s}, 72^{\circ} \mathrm{C}$ for $60 \mathrm{~s}, 35$ cycles of $95{ }^{\circ} \mathrm{C}$ for $30 \mathrm{~s}, 50{ }^{\circ} \mathrm{C}$ for $30 \mathrm{~s}, 72{ }^{\circ} \mathrm{C}$ for $60 \mathrm{~s}$ and a final extension at $72{ }^{\circ} \mathrm{C}$ for $5 \mathrm{~min}$. A negative control was also generated at this stage by exposing $25 \mu \mathrm{l}$ of PCR reaction mix and no DNA template to the same PCR cycle to ensure no contamination or false amplification occurred during the primerless PCR process.

In order to investigate the efficacy of the primerless PCR process we chose low quality and quantity samples for comparison. The samples chosen were identified by lack of gel band presence, brightness and/or clarity following optimised DNA extraction and amplification (Jacobs et al. 2013; Thiel et al. 2014) of the 203 bp region of cytochrome b gene outlined above. Samples consisted of: 10 plumulaceous feathers, one secondary feather, and one egg shell. Each sample was used as a substrate for the amplification of the barcoding region of the cytochrome oxidase I gene using primer set AWCF1 and AWCintR2 (C1; 328 bp) (Patel et al. 2010), as described in the small amplicon strategy section below, with and without a prior primerless PCR stage. A standardised dilution factor was used to ensure the same amount of DNA template was used in each primered PCR reaction. Following amplification, the samples were visualised on the UV transilluminator as a comparison for effective amplification with and without exposure to primerless PCR. This can be seen 


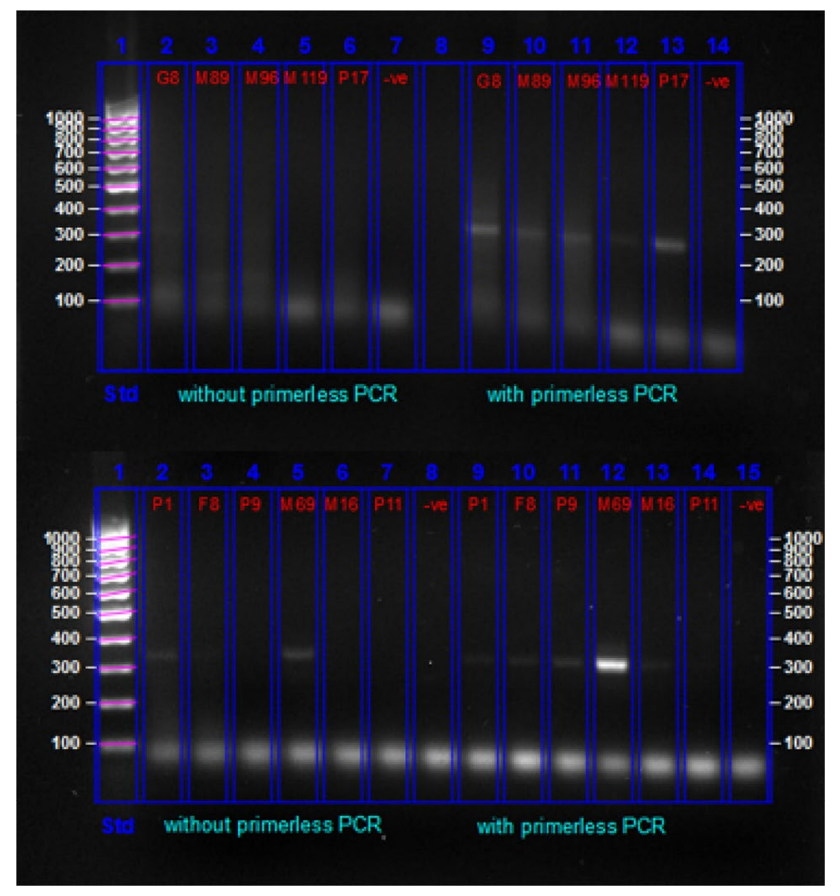

Fig. 2 Gel image showing the amplification of non-invasively collected plumulaceous feather samples [with the exception one secondary feather (G8)] using primer set AWCF1 and AWCintR2 (328 bp) (Patel et al. 2010) both with and without exposure to primerless PCR

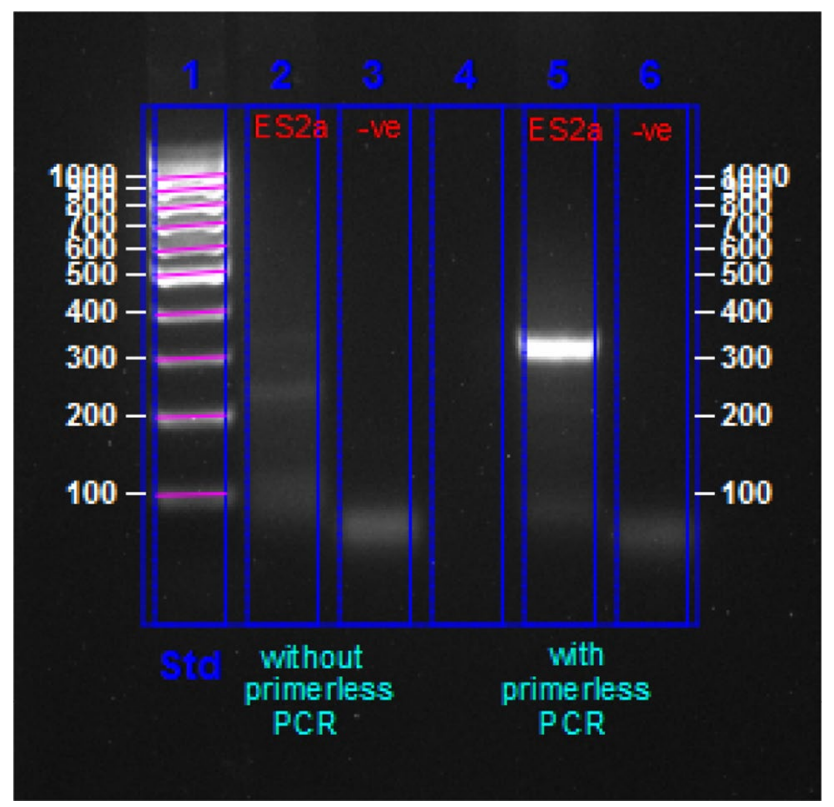

Fig. 3 Gel image showing the amplification of a non-invasively collected egg shell sample using primer set AWCF1 and AWCintR2 (328 bp) (Patel et al. 2010) both with and without exposure to primerless PCR for feather samples in Fig. 2 and the egg shell sample in Fig. 3, which show that more bands were present and were more defined after the addition of the primerless PCR step. Nine of the twelve samples failed to amplify without the addition of primerless PCR but successfully amplified and presented clear bands when exposed to primerless PCR. For example, sample 69 (Fig. 2) shows a brighter and more defined band is present after under-going the primerless PCR process. The increased prevalence of bands and the improved clarity, brightness and definition of the present bands after primerless PCR indicates the improved quality of DNA after exposure to this process.

\section{Small amplicon strategy}

The third step we adopted was a small amplicon strategy to successfully amplify and sequence three small overlapping amplicons, which were combined to construct a longer and more informative section of the gene. Small amplicons have an increased likelihood of amplification (Broquet et al. 2006; Fischer et al. 2016; Debode et al. 2017) thus we targeted 200-250 bp amplicons (Rohland and Hofreiter 2007; Stiller et al. 2009). We performed primered PCR on our samples, following inclusion of the primerless PCR step, along with a primerless negative control and a standard negative control, using the following overlapping primer sets, which are known to amplify Columbiforme COI barcoding region: $\mathrm{AWCF} 1$ and $\mathrm{AWCintR} 2(\mathrm{C} 1 ; 328 \mathrm{bp}), \mathrm{AWCintF} 2$ and AWCintR4 (C2; 314 bp), AWCintF4 and AWCR6 (C3; 350 bp) (Patel et al. 2010). The PCR reaction was subjected to the same cycling parameters as used in the primerless PCR stage: initial denaturation at $95{ }^{\circ} \mathrm{C}$ for $5 \mathrm{~min}, 10$ cycles of $95{ }^{\circ} \mathrm{C}$ for $30 \mathrm{~s}, 55^{\circ} \mathrm{C}$ for $30 \mathrm{~s}, 72{ }^{\circ} \mathrm{C}$ for $60 \mathrm{~s}, 35$ cycles of $95{ }^{\circ} \mathrm{C}$ for $30 \mathrm{~s}, 50{ }^{\circ} \mathrm{C}$ for $30 \mathrm{~s}, 72{ }^{\circ} \mathrm{C}$ for $60 \mathrm{~s}$ and a final extension at $72{ }^{\circ} \mathrm{C}$ for $5 \mathrm{~min}$. PCR products were separated and visualised using agarose-gel electrophoresis. All three primer sets successfully amplified DNA from our non-invasively collected samples (Fig. 4). Samples were purified using the QIAquick PCR Purification as per the manufacturer's protocol (QIAGEN Inc., Crawley). Samples were then prepared for sequencing using the Mix2Seq Kit (Eurofins Genomics, Luxembourg) according to the manufacturer's instructions and submitted to Eurofins Genomics, where they were sequenced using Sanger sequencing methods.

Sequence data for the three overlapping regions were reconstructed to create an approximately $650 \mathrm{bp}$ sequence (Fig. 5a). Firstly, consensus sequences were obtained for each amplicon by aligning the forward and reverse sequence data in NCBI Basic Local Alignment Search Tool (BLAST®) (Johnson et al. 2008) and were used in all further reconstructions and alignments. Obtaining consensus sequence is particularly important when using primerless PCR as random fragmentation and self-priming 


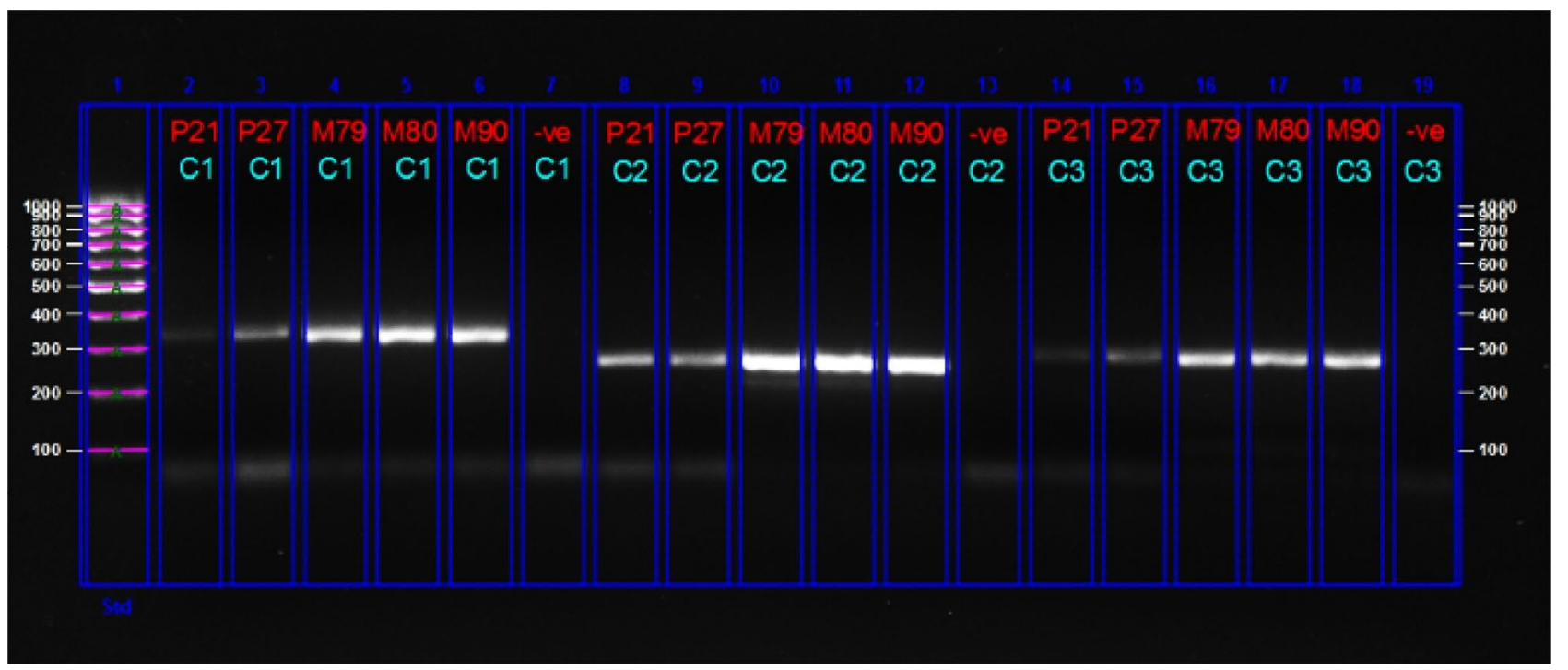

Fig. 4 Gel image showing successful amplification of the three small amplicons using primer sets AWCF1 and AWCintR2 (C1; 328 bp), AWCintF2 and AWCintR4 (C2; $314 \mathrm{bp),} \mathrm{AWCintF4} \mathrm{and} \mathrm{AWCR6}$

can introduce artificial recombinants or base errors but this can be counteracted by using consensus sequence (Weber et al. 2000). To assemble the longer combined sequence, each of the small amplicons were aligned using a global alignment algorithm with Emboss Explorer merger tool (Fig. 5b). A heuristic approach is used to select the base with the best local sequence quality score in the case of any mismatches (Bell and Kramvis 2013). Highly degraded DNA can produce poor read length or low quality base calls in the sequence data, particularly at the ends of the trace producing "messy" end sequences (Bell and Kramvis 2013). Therefore, most probably due to the highly degraded nature of the samples used in this study, some base inconsistencies were recognised. In these cases the Emboss Merger local quality score, along with the electropherogram obtained from Eurofins for each sequence (Fig. 5c), were assessed and the base with the highest quality score as per both the emboss and Eurofins sequence quality assessment was selected (Bell and Kramvis 2013). Due to the non-invasive sample collection method used for these samples, along with the inability to identify the species from the morphological features of the feather alone, each sequence was run in NCBI's Basic Local Alignment Search Tool (BLAST $\left.{ }^{\circledR}\right)$ to predict species identification (Johnson et al. 2008). This search indicated that the sample, presented in Fig. 5, was from the Caribbean columbid, white-crowned pigeon (Patagioenas leucocephala), with a BLAST total score of 989 and a query coverage of 91\% to Genbank sequence JJQ175689.1 (Schindel et al. 2011). Combined sequence data obtained from the three small amplicons were aligned with the corresponding COI
(C3; 350 bp) (Patel et al. 2010) from moulted plumulaceous feathers collected non-invasively and opportunistically in the field

barcoding region sequence data from a known $L$. wellsi specimen (unpublished data-Genbank reference sequence not yet available for this species) and P. leucocephala (accession number JQ175689.1) (Schindel et al. 2011) to confirm the expected nitrogenous base positions (Johnson et al. 2008), which is particularly important given the possibility of potential base errors introduced by primerless PCR (Weber et al. 2000). Target-species was confirmed for the $650 \mathrm{bp}$ length of the COI barcoding region from non-invasively collected plumulaceous feather samples.

\section{Discussion}

The methods outlined in this study: an optimised userdeveloped DNA extraction protocol, use of a primerless PCR technique, and a small amplicon PCR strategy, facilitated the attainment of target-species mtDNA sequence data of $650 \mathrm{bp}$ in length from non-invasively collected plumulaceous feather samples. Problems arising due to poor quality of DNA extracted from non-invasively collected samples can often dissuade researchers from proceeding with genetic analysis, causing the potential of such samples to go unrecognised (Horváth et al. 2005; Speller et al. 2011). This can also lead to a preference in invasive as opposed to non-invasive sample collection methods due to the higher confidence in invasive sample quality (Johnson and Clayton 2000a; Harvey et al. 2006). The methods we have outlined allow such samples, which previously may have been discounted for genetic analysis, to be successfully used to obtain informative sequence data. 


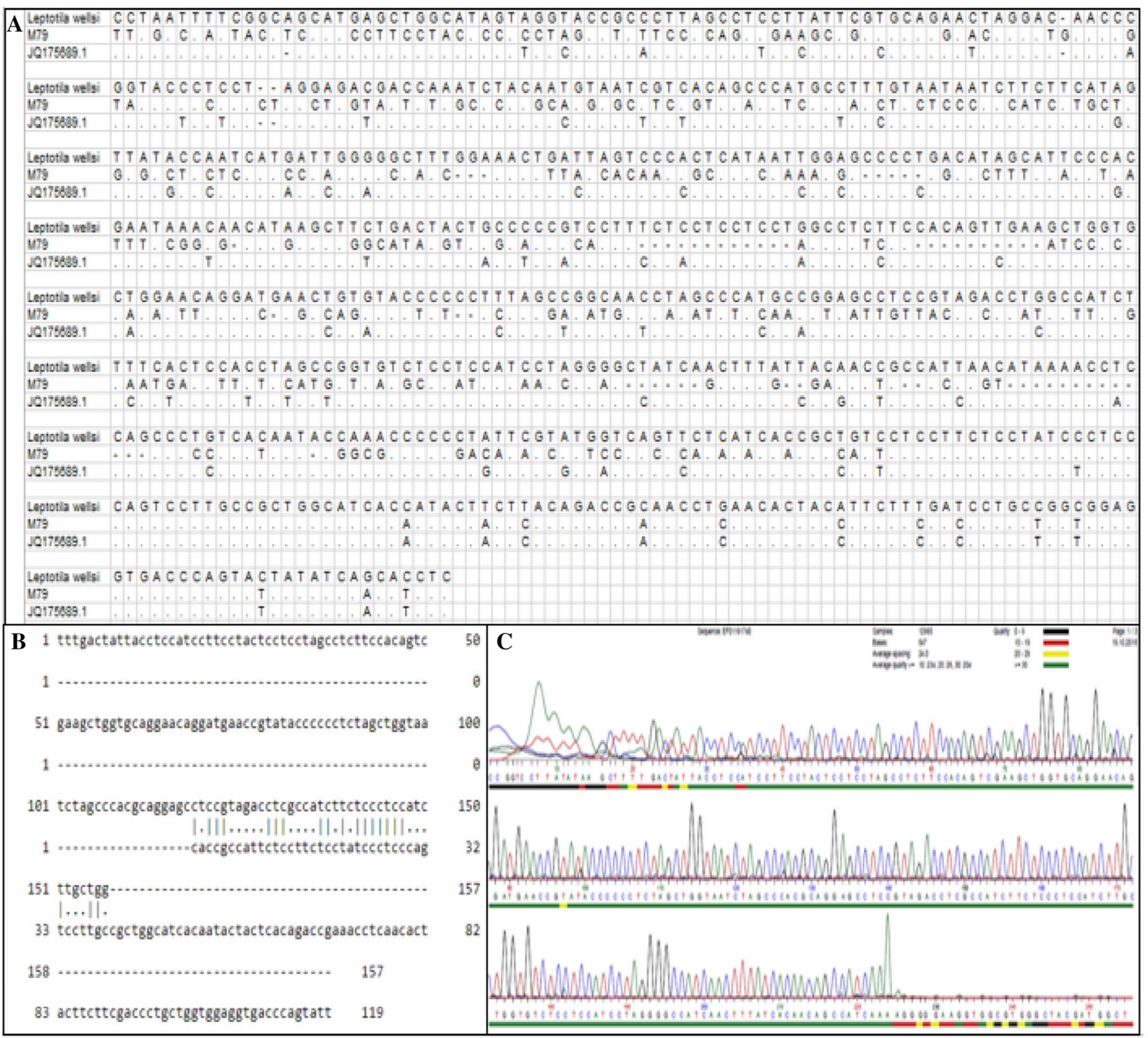

Fig. 5 Sequence data from sample M79. a The 650 bp sequence obtained for sample M79 aligned with the corresponding COI barcoding region sequence data for Leptotila wellsi and Patagioenas leucocephala, labelled with its accession number JQ175689.1 (Schindel et al. 2011). b Emboss Explorer (Bell and Kramvis 2013) OUTPUT example for two overlapping sequences from sample M79 using forward and reverse consensus sequences. c Electropherogram example with base quality score as assigned by Eurofins for the forward sequence of COI_2
It is widely documented that feather type influences the success and yield of DNA extraction from feather samples (Bayard De Volo et al. 2008; Hogan et al. 2008). Primary feathers are widely used as a resourse for genetic monitoring of wild bird populations, as they often contain a blood clot located in the superior umbilicus of the feather shaft (Horváth et al. 2005). Along with assessing the genetic variation within populations (Nichols et al. 2001), feather samples have been used to investigate phylogeny and biogeography (Johnson and Clayton 2000b), and to understand the impact of anthropological processes on genetic structure and gene flow (Fourcade et al. 2016) of bird species. However, a study on molecular sexing and microsatellite genotyping of hyacinth macaw (Anodorhynchus hyacinthinus) found that despite using larger moulted feathers (with a size greater than $20 \mathrm{~cm}$ ) than in this study, feathers that spent more than 7 days in the field and were of poor physical quality, had a low success rate in yielding sufficient DNA for genetic analysis (Presti et al. 2013). Nevertheless, we have demonstrated that plumulaceous feathers that are found in the field 
do not necessarily need to be excluded from sample sets as they can still be utilised to yield informative data.

The use of primerless PCR increased the amplification success in subsequent PCR reactions for samples that had proven difficult to amplify. Bands from samples exposed to primerless PCR were visually clearer and brighter, which suggests a higher quality of DNA (Hughes-Stamm et al. 2011; Jacobs et al. 2013; Lucena-Aguilar et al. 2016). Primerless PCR has been used in studies of ancient DNA, including that of Weber et al. (2000), who increased the successful amplification of ancient DNA from bone samples when investigating the population bottleneck of the northern elephant seal (Weber et al. 2000). The same technique was adopted using museum samples from the African horseshoe bat (Rhinolophus darlingi) to investigate the phenotypic convergence of its evolutionary history (Jacobs et al. 2013). Both studies reported that primerless PCR improved the recovery of DNA from ancient samples but did not comment on differences in DNA quality post primerless PCR (Weber 2004; Jacobs et al. 2013). To the best of our knowledge, our study is the first to demonstrate the utility of primerless PCR to increase DNA quality for degraded non-invasive feather samples and demonstrates that this technique can be applied to a variety of non-invasive samples collected in the field.

Although the primerless PCR technique recovers the quality of DNA obtained from the degraded samples this process does not completely repair damaged DNA, particularly when the DNA damage is highly fragmented, which is a common problem with samples kept in non-optimal conditions (Diegoli et al. 2012). The varying quality of sequence data at ends of the trace producing "messy" end sequences is a particular problem for overlapping regions resulting in base inconsistencies (Stiller et al. 2009). However, this is not specific to the techniques we describe here and is prevalent in many genetics datasets, though it is not widely documented (Sobel et al. 2002; Hackett and Broadfoot 2003; Bonin et al. 2004). Sequencing error can lead to misidentification of individuals, misinterpretations and erroneous conclusions to be drawn from genetic analysis of relatedness and population structure (Hogan et al. 2008). Sequencing error can occur at any stage when obtaining genetic information but there are a number of actions that can be taken to minimise these errors (Bonin et al. 2004). The following have been adopted in this study and are proposed for future studies to limit the risk of sequencing error following primerless PCR: (1) the amplification of small amplicons because genotyping error correlates with amplicon size (Vili et al. 2013); (2) the inclusion of negative controls (Waits and Paetkau 2005; Alda et al. 2007; Boonseub et al. 2012); (3) sequence quality assurance by using only forward and reverse consensus sequences with further analysis and inspection of electropherogram scoring levels; and (4) cross-reading and aligning sequence data with reference samples (Weber et al. 2000; Bonin et al. 2004). For downsteam analyses, it is also recommended to include a sequencing error rate when using genetic data for population and phylogenetic analyses (Bonin et al. 2004).

We have outlined methods that achieve successful extraction and amplification of an informative length of mtDNA from non-invasively collected plumulaceous feather samples. The analysis of mtDNA has many practical applications in conservation including species identification as well as presence/absence detection. The high mutation rate of mtDNA in comparison to nDNA allows the identification of Evolutionarily Significant Units (ESUs), giving an insight into the phylogenetics of a species (Cronin 1993; Wan et al. 2004; Gupta and Bhardwaj 2013). Data pertaining to phylogenetics have multiple conservation implications including evolutionary divergence and speciation, along with phylogeography and rates of change relating to morphology and behaviour of a species (Huang et al. 2009). Determining the point at which speciation occurs or defining a species as genetically distinct-known as the phylogenetic species concept-is particularly useful for resolving taxonomic uncertainties, outlining wildlife legislation, and in identifying conservation priorities (Hazevoet 1996; Wan et al. 2004; Pellens and Grandcolas 2016; Chen et al. 2018). Analysis of mtDNA can be used to make long-term species conservation action plans from an evolutionary perspective (Nielsen et al. 2017) and to inform short-term demographic management of populations through identification of population change and connectivity therefore providing information on the effects of habitat fragmentation (Cronin 1993; Moritz 1994; Nabholz et al. 2009). Therefore, our improved methods of extraction and amplification of mtDNA from non-invasively collected, low quality feather samples, have the potential to extend the applicability of molecular analyses in studies aimed at the conservation of endangered bird species, for which it is typically difficult to obtain high quality samples.

\section{Conclusion}

In conclusion, the optimised user-developed DNA extraction protocol, along with the use of the primerless PCR technique, and a small amplicon PCR strategy, are sufficient to enable DNA extraction and mtDNA amplification from moulted plumulaceous feathers collected non-invasively and opportunistically in the field. This not only provides evidence in support of using non-invasive sampling methods for genetic analyses, in particular when applied to endangered species, but also highlights the utility of biological material kept in non-optimal conditions, may previously have been discounted (Rawlence et al. 2009; Vili et al. 2013). Data collected in this manner is informative for species identification, presence/absence detection, population structure and 
phylogenetic analyses of rare and elusive species (Bonin et al. 2004; Marucco et al. 2011; Adam et al. 2014), all of which are key questions in conservation research.

Acknowledgements We would like to thank the Forest and National Parks Department of the Government of Grenada, in particular Anthony Jeremiah and Doland Francis, along with the Grenada Dove Conservation Programme for providing us with the samples. I would like to thank David Appleton, Laura Hough, Rebecca Chawner, Alice McCourt and other biological sciences students for their assistance in the field. I would also like to thank Achaz von Hardenberg and Matt Geary for their useful discussions about this manuscript. This work was funded by the University of Chester.

Open Access This article is distributed under the terms of the Creative Commons Attribution 4.0 International License (http://creativeco mmons.org/licenses/by/4.0/), which permits unrestricted use, distribution, and reproduction in any medium, provided you give appropriate credit to the original author(s) and the source, provide a link to the Creative Commons license, and indicate if changes were made.

\section{References}

Adam I, Scharff C, Honarmand M (2014) Who is who?. J Vis Exp, Non-invasive methods to individually sex and mark altricial chicks. https://doi.org/10.3791/51429

Ahlers N, Creecy J, Frankham G et al (2017) "ForCyt" DNA database of wildlife species. Forensic Sci Int. https://doi.org/10.1016/j. fsigss.2017.09.195

Alda F, Rey I, Doadrio I (2007) An improved method of extracting degraded DNA samples from birds and other species. Ardeola 54:331-334

An Y, Chen L, Sun S et al (2011) QuikChange shuffling: a convenient and robust method for site-directed mutagenesis and random recombination of homologous genes. N Biotechnol 28:320-325. https://doi.org/10.1016/J.NBT.2011.03.001

Bayard De Volo S, Reynolds RT, Douglas MR, Antolin MF (2008) An improved extraction method to increase DNA yield from molted feathers. Condor 110:762-766. https://doi.org/10.1525/ cond.2008.8586

Bell TG, Kramvis A (2013) Fragment merger: an online tool to merge overlapping long sequence fragments. Viruses 5:824833. https://doi.org/10.3390/v5030824

BirdLife International (2019) Grenada Dove (Leptotila wellsi)BirdLife species factsheet. In: IUCN Red List birds. http://dataz one.birdlife.org/species/factsheet/grenada-dove-leptotila-wells i. Accessed 29 Mar 2019

Blockstein DE, Hardy JW (1989) The grenada dove (Leptotila wellsi) is a distinct species. Auk 106:334-340

Bohmann K, Evans A, Gilbert MTP et al (2014) Environmental DNA for wildlife biology and biodiversity monitoring. Trends Ecol Evol 29:358-367. https://doi.org/10.1016/J.TREE.2014.04.003

Bolton NM, Van Oosterhout C, Collar NJ, Bell DJ (2016) Population constraints on the Grenada Dove Leptotila wellsi: preliminary findings and proposals from south-west Grenada. Bird Conserv Int BirdLife Int 26:205-213. https://doi.org/10.1017/s0959 270915000064

Bonin A, Bellemain E, Bronken Eidesen P et al (2004) How to track and assess genotyping errors in population genetics studies. Mol Ecol 13:3261-3273. https://doi.org/10.1111/j.1365294X.2004.02346.x

Boonseub S, Johnston G, Linacre A (2012) Identification of protected avian species using a single feather barb. J Forensic Sci
57:1574-1577. https://doi.org/10.1111/j.1556-4029.2012.02206 $\mathrm{x}$

Brakmann S, Schwienhorst A (2004) Evolutionary methods in biotechnology : clever tricks for directed evolution. Wiley-VCH, New York

Broquet T, Ménard N, Petit E (2006) Noninvasive population genetics: a review of sample source, diet, fragment length and microsatellite motif effects on amplification success and genotyping error rates. Conserv Genet 8:249-260. https://doi.org/10.1007/ s10592-006-9146-5

Bruns DE, Ashwood ER, Burtis CA (2007) Fundamentals of molecular diagnostics. Saunders Elsevier, Amsterdam

Bush KL, Vinsky MD, Aldridge CL, Paszkowski CA (2005) A comparison of sample types varying in invasiveness for use in DNA sex determination in an endangered population of greater Sage-Grouse (Centrocercus uropihasianus). Conserv Genet 6:867-870. https://doi.org/10.1007/s10592-005-9040-6

Chen X, Li R, Wang C et al (2018) An effective method for identification of three mussel species and their hybrids based on SNPs. Conserv Genet Resour. https://doi.org/10.1007/s1268 6-018-1051-y

Coghlan ML, White NE, Parkinson L et al (2012) Egg forensics: an appraisal of DNA sequencing to assist in species identification of illegally smuggled eggs. Forensic Sci Int Genet 6:268-273. https://doi.org/10.1016/j.fsigen.2011.06.006

Cronin MA (1993) In my experience: mitochondrial DNA in wildlife taxonomy and conservation biology: cautionary notes. Wildl Soc Bull 21:339-348

Dai Y, Lin Q, Fang W et al (2015) Noninvasive and nondestructive sampling for avian microsatellite genotyping: a case study on the vulnerable Chinese Egret (Egretta eulophotes). Avian Res 6:24. https://doi.org/10.1186/s40657-015-0034-x

Debode F, Marien A, Janssen É et al (2017) The influence of amplicon length on real-time PCR results. Biotechnol Agron Soc Env 21:3-11

Dieffenbach CW, Lowe TMJ, Dveksler GS (1993) General concepts for PCR primer design. Genome Res 3(3):S30-S37

Diegoli TM, Farr M, Cromartie C et al (2012) An optimized protocol for forensic application of the PreCR ${ }^{\mathrm{TM}}$ repair mix to multiplex STR amplification of UV-damaged DNA. Forensic Sci Int Genet 6:498-503. https://doi.org/10.1016/J.FSIGEN.2011.09.003

Dove CJ (2000) A descriptive and phylogenetic analysis of plumulaceous feather characters in charadriiformes. Ornithol Monogr. https://doi.org/10.2307/40166844

Fischer M, Renevey N, Thür B et al (2016) Efficacy assessment of nucleic acid decontamination reagents used in molecular diagnostic laboratories. PLoS ONE 11:1-9. https://doi.org/10.1371/ journal.pone.0159274

Fourcade Y, Richardson DS, Keišs O et al (2016) Corncrake conservation genetics at a European scale: the impact of biogeographical and anthropological processes. Biol Conserv 198:210-219. https://doi.org/10.1016/j.biocon.2016.04.018

Gebhardt KJ, Waits LP (2008) High error rates for avian molecular sex identification primer sets applied to molted feathers. J F Ornithol. https://doi.org/10.1111/j.1557-9263.2008.00175.x

Graziano L, El-Mogy M, Haj-Ahmad Y (2013) Effect of elution volume on DNA recovery and quality using Norgen's blood genomic DNA isolation micro kit. Boston University, Boston

Gupta A, Bhardwaj A (2013) Mitochondrial DNA-a tool for phylogenetic and biodiversity search in equines. J Biodivers Endanger Species 01:1-8. https://doi.org/10.4172/2332-2543.S1-006

Hackett CA, Broadfoot LB (2003) Effects of genotyping errors, missing values and segregation distortion in molecular marker data on the construction of linkage maps. Heredity (Edinb) 90:3338. https://doi.org/10.1038/sj.hdy.6800173 
Haddad Y, Dostalova S, Kudr J et al (2017) DNA-magnetic particle binding analysis by dynamic and electrophoretic light scattering. J Vis Exp. https://doi.org/10.3791/56815

Hanson EK, Ballantyne J (2005) Whole genome amplification strategy for forensic genetic analysis using single or few cell equivalents of genomic DNA. Anal Biochem 346:246-257. https://doi. org/10.1016/J.AB.2005.08.017

Harvey MG, Bonter DN, Stenzler LM, Lovette IJ (2006) A comparison of plucked feathers versus blood samples as DNA sources for molecular sexing. J F Ornithol 77:136-140. https://doi.org/ 10.1111/j.1557-9263.2006.00033.x

Hazevoet CJ (1996) Conservation and species lists: taxonomic neglect promotes the extinction of endemic birds, as exemplified by taxa from eastern Atlantic islands. Bird Conserv Int 6:181-196. https://doi.org/10.1017/S0959270900003063

Hogan FE, Cooke R, Burridge CP, Norman JA (2008) Optimizing the use of shed feathers for genetic analysis. Mol Ecol Resour. https ://doi.org/10.1111/j.1471-8286.2007.02044.x

Horváth MB, Martínez-Cruz B, Negro JJ et al (2005) An overlooked DNA source for non-invasive genetic analysis in birds. J Avian Biol 36:84-88. https://doi.org/10.1111/j.0908-8857.2005.03370.x

Huang Z, Liu N, Xiao Y et al (2009) Phylogenetic relationships of four endemic genera of the Phasianidae in China based on mitochondrial DNA control-region genes. Mol Phylogenet Evol 53:378383. https://doi.org/10.1016/j.ympev.2009.07.002

Hughes-Stamm SR, Ashton KJ, Van Daal A (2011) Assessment of DNA degradation and the genotyping success of highly degraded samples. Int J Legal Med. https://doi.org/10.1007/s0041 4-010-0455-3

Jacobs DS, Babiker H, Bastian A et al (2013) Phenotypic convergence in genetically distinct lineages of a rhinolophus species complex (Mammalia, Chiroptera). PLoS ONE 8:e82614. https://doi. org/10.1371/journal.pone.0082614

Johnson KP, Clayton DH (2000a) A molecular phylogeny of the dove genus zenaida: mitochondrial and nuclear DNA sequences. Condor 102:864-870

Johnson KP, Clayton DH (2000b) Nuclear and mitochondrial genes contain similar phylogenetic signal for pigeons and doves (Aves: Columbiformes). Mol Phylogenet Evol 14:141-151

Johnson M, Zaretskaya I, Raytselis Y et al (2008) NCBI BLAST: a better web interface. Nucleic Acids Res 36:W5-W9. https://doi. org/10.1093/nar/gkn201

Kishore R, Reef Hardy W, Anderson VJ et al (2006) Optimization of DNA extraction from low-yield and degraded samples using the BioRobot EZ1 and BioRobot M48. J Forensic Sci 51:1055-1061. https://doi.org/10.1111/j.1556-4029.2006.00204.x

Koressaar T, Remm M (2007) Enhancements and modifications of primer design program Primer3. Bioinformatics 23:1289-1291. https://doi.org/10.1093/bioinformatics/btm091

Lucena-Aguilar G, Sánchez-López AM, Barberán-Aceituno C et al (2016) DNA source selection for downstream applications based on DNA quality indicators analysis. Biopreserv Biobank $14: 264-270$

Mardis E, McCombie WR (2017) Agarose gel size selection for DNA sequencing libraries. Cold Spring Harb Protoc. https://doi. org/10.1101/pdb.prot094698

Marucco F, Boitani L, Pletscher DH, Schwartz MK (2011) Bridging the gaps between non-invasive genetic sampling and population parameter estimation. Eur J Wildl Res 57:1-13. https://doi. org/10.1007/s10344-010-0477-7

McNally L, Shaler RC, Baird M et al (1989) Evaluation of deoxyribonucleic acid (DNA) isolated from human bloodstains exposed to ultraviolet light, heat, humidity, and soil contamination. J Forensic Sci 34:12741J. https://doi.org/10.1520/JFS12741J

Melnikov A, Youngman PJ (1999) Random mutagenesis by recombinational capture of PCR products in Bacillus subtilis and
Acinetobacter calcoaceticus. Nucleic Acids Res 27:1056-1062. https://doi.org/10.1093/nar/27.4.1056

Meteostat (2018) Climate Gouyave, grenada-monthly weather averages I meteostat. In: meteostat.net. https://www.meteostat.net/ climate/gouyave. Accessed 14 Apr 2018

Mills LS, Citta JJ, Lair KP et al (2000) Estimating animal abundance using noninvasive DNA sampling: promise and pitfalls. Ecol Appl 10:283-294

Moritz C (1994) Applications of mitochondrial DNA analysis in conservation: a critical review. Mol Ecol 3:401-411. https://doi. org/10.1111/j.1365-294X.1994.tb00080.x

Nabholz B, Glémin S, Galtier N (2009) The erratic mitochondrial clock: variations of mutation rate, not population size, affect mtDNA diversity across birds and mammals. BMC Evol Biol 9:54. https://doi.org/10.1186/1471-2148-9-54

Naqib A, Jeon T, Kunstman K et al (2019) PCR effects of melting temperature adjustment of individual primers in degenerate primer pools. PeerJ 7:e6570. https://doi.org/10.7717/peerj.6570

Nelson HP, Devenish-Nelson ES, Rusk BL et al (2018) A call to action for climate change research on Caribbean dry forests. Reg Environ Change 18:1337-1342. https://doi.org/10.1007/ s10113-018-1334-6

Nichols RA, Bruford MW, Groombridge JJ (2001) Sustaining genetic variation in a small population: evidence from the Mauritius kestrel. Mol Ecol 10:593-602

Nielsen ES, Beger M, Henriques R et al (2017) Multispecies genetic objectives in spatial conservation planning. Conserv Biol 31:872-882. https://doi.org/10.1111/cobi.12875

Pacheco MA, Battistuzzi FU, Lentino M et al (2011) Evolution of modern birds revealed by mitogenomics: timing the radiation and origin of major orders. Mol Biol Evol 28:1927-1942. https ://doi.org/10.1093/molbev/msr014

Patel S, Waugh J, Millar CD, Lambert DM (2010) Conserved primers for DNA barcoding historical and modern samples from New Zealand and Antarctic birds. Mol Ecol Resour 10:431-438. https://doi.org/10.1111/j.1755-0998.2009.02793.x

Pellens R, Grandcolas P (2016) Phylogenetics and conservation biology: drawing a path into the diversity of life. Biodiversity conservation and phylogenetic systematics. Springer, Cham, pp $1-15$

Presti FT, Meyer J, Antas PTZ et al (2013) Non-invasive genetic sampling for molecular sexing and microsatellite genotyping of hyacinth macaw (Anodorhynchus hyacinthinus). Genet Mol Biol 36:129-133

R Core Team (2013) R: a language and environment for statistical computing. R Foundation for Statistical Computing, Vienna

Rawlence NJ, Wood JR, Armstrong KN, Cooper A (2009) DNA content and distribution in ancient feathers and potential to reconstruct the plumage of extinct avian taxa. Proc Biol Sci 276:3395-3402. https://doi.org/10.1098/rspb.2009.0755

Rivera-Milán FF, Bertuol P, Simal F, Rusk BL (2015) Distance sampling survey and abundance estimation of the critically endangered Grenada Dove (Leptotila wellsi). The Condor 117:87-93. https://doi.org/10.1650/condor-14-131.1

Rohland N, Hofreiter M (2007) Ancient DNA extraction from bones and teeth. Nat Protoc 2:1756-1762. https://doi.org/10.1038/ nprot.2007.247

Rosenberg J, Korsmo FL (2001) Local participation, international politics, and the environment: the World Bank and the Grenada Dove. J Environ Manage 62:283-300

Rudnick JA, Katzner TE, Dewoody JA (2009) In: andbook of nature conservation genetic analyses of noninvasively collected feathers can provide new insights into avian demography and behavior. Nova Science Publishers Inc, New York

Rusk BL (2008) Important bird areas in the Caribbean: Grenada. Birdlife International Conservation Series 15 
Rusk BL (2017) Long-term population monitoring of the Critically Endangered Grenada Dove (Leptotila wellsi) on Grenada, West Indies. J Caribb Ornithol 30:49-56

Sangali S, Brandelli A (2000) Feather keratin hydrolysis by a Vibrio sp. strain kr2. J Appl Microbiol 89:735-743. https://doi.org/10. 1046/j.1365-2672.2000.01173.x

Schindel DE, Stoeckle MY, Milensky C et al (2011) DNA barcodes of bird species in the national museum of natural history, Smithsonian institution, USA. Zookeys. https://doi.org/10.3897/zooke ys. 152.2473

Segelbacher G (2002) Noninvasive genetic analysis in birds: testing reliability of feather samples. Mol Ecol Notes 2:367-369. https ://doi.org/10.1046/j.1471-8286.2002.00180.x-i2

Seki S-I (2006) Application of molted feathers as noninvasive samples to studies on the genetic structure of pigeons (Aves: Columbidae). J For Res 11:125-129. https://doi.org/10.1007/s10310-005-0194-3

Shapiro SS, Francia RS (1972) An approximate analysis of variance test for normality. J Am Stat Assoc 67:215-216. https://doi. org/10.1080/01621459.1972.10481232

Sobel E, Papp JC, Lange K (2002) Detection and integration of genotyping errors in statistical genetics. Am J Hum Genet 70:496-508. https://doi.org/10.1086/338920

Speller CF, Nicholas GP, Yang DY (2011) Feather barbs as a good source of mtDNA for bird species identification in forensic wildlife investigations. Investig Genet 2:16. https://doi. org/10.1186/2041-2223-2-16

Stemmer WP (1994) DNA shuffling by random fragmentation and reassembly: in vitro recombination for molecular evolution. Proc Natl Acad Sci USA 91:10747-10751

Stiller M, Knapp M, Stenzel U et al (2009) Direct multiplex sequencing (DMPS)-a novel method for targeted high-throughput sequencing of ancient and highly degraded DNA. Genome Res 19:1843-1848. https://doi.org/10.1101/gr.095760.109

Suenaga H, Goto M, Furukawa K (2005) DNA Shuffling. Evolutionary methods in biotechnology. Wiley-VCH Verlag $\mathrm{GmbH} \& \mathrm{Co}$. KGaA, Weinheim, pp 13-24

Thiel CS, Tauber S, Schütte A et al (2014) Functional activity of plasmid dna after entry into the atmosphere of earth investigated by a new biomarker stability assay for ballistic spaceflight experiments. PLoS ONE. https://doi.org/10.1371/journal.pone.0112979
Untergasser A, Cutcutache I, Koressaar T et al (2012) Primer3-new capabilities and interfaces. Nucleic Acids Res 40:e115. https:// doi.org/10.1093/nar/gks596

Vili N, Nemesházi E, Kovács S et al (2013) Factors affecting DNA quality in feathers used for non-invasive sampling. J Ornithol 154:587-595. https://doi.org/10.1007/s10336-013-0932-9

von Thaden A, Cocchiararo B, Jarausch A et al (2017) Assessing SNP genotyping of noninvasively collected wildlife samples using microfluidic arrays. Sci Rep 7:10768. https://doi.org/10.1038/ s41598-017-10647-w

Waits LP, Paetkau D (2005) Noninvasive genetic sampling tools for wildlife biologists: A review of applications and recommendations for accurate data collection. J Wildl Manage 69:1419-1433

Wan Q-H, Wu H, Fujihara T, Fang S-G (2004) Review which genetic marker for which conservation genetics issue? Electrophoresis 25:2165-2176. https://doi.org/10.1002/elps.200305922

Weber DS (2004) Genetic consequences of a severe population bottleneck in the Guadalupe Fur Seal (Arctocephalus townsendi). J Hered 95:144-153. https://doi.org/10.1093/jhered/esh018

Weber D, Stewart BS, Garza JC, Lehman N (2000) An empirical genetic assessment of the severity of the northern elephant seal population bottleneck. Curr Biol 10:1287-1290. https://doi. org/10.1016/S0960-9822(00)00759-4

Westermeier R (2005) Electrophoresis in practice : a guide to methods and applications of DNA and protein separations. Wiley, New York

Wilcox RR (2008) Adjusting for unequal variances when comparing means in one-way and two-way fixed effects ANOVA models. J Educ Stat 14:269-278. https://doi.org/10.3102/107699860140032 69

Zhou C, Ling X (2011) DNA binding and DNA extraction: methods, applications, and limitations. Nova Science Publishers Inc, New York

Publisher's Note Springer Nature remains neutral with regard to jurisdictional claims in published maps and institutional affiliations. 